\title{
Women's Participation in Managerial Activities: A Study on Employed Women in Selected Enterprises of Bangladesh
}

\author{
Nazneen Jahan Chowdhury*
}

\begin{abstract}
Women being a significant part of population have been found involved in managerial activities. But the degree of participation of women is still insignificant in Bangladesh because of different reasons such as social, cultural and political barriers, inadequate implementation of constitutional and legal provisions, lack of proper institutional and organizational structures etc. In view of these, the present study has been undertaken aiming at assessing the involvement of women in managerial activities of different industries. Of the number of industries that influence women in management, the eleven identifiable sectors have been selected based on purposive sampling technique. This study has revealed that women have multiple responsibilities at home and at work place. When comparisons were made with their male counterparts, women managers have been equally well educated and were found to be equally capable, creative, innovative and competent. They also have the potential of being trained up and to contribute to the development activities as effectively as a man perform. To effectively manage this transition, amongst others followings main interventions have been proposed: proper implementation of constitutional and legal provisions, change of customs and social practices that prevent women development, institutionalization of women's interests, development of appropriate training courses for women managers.
\end{abstract}

Key words: Women, Participation, Women's Participation, Management

\footnotetext{
* Assistant Professor, Department of Business Administration, International Islamic University Chittagong.
} 


\section{Introduction:}

The overall development of a country depends upon the maximum utilization of her people, both men and women. The Fifth Five Year Plan (1997-2002) of Bangladesh recognizes that women represent a half of the country's potential for development. But women's participation in formal sector employment was negligible until the recent past.

Women are identified with domestic life while decision making is viewed as a male-dominated activity that is typically masculine in nature. With the advancement of time, the fact has now been recognized that without ensuring women's development, the national development cannot be achieved and sustained. Women's equal participation in management plays a pivotal role in the general process of the advancement of women. It is not only a demand for simple justice or democracy but can also be seen as a necessary condition for women's interests to be taken into account. Without the active participation of women and the incorporation of women's perspective at all levels of decision-making, the goals of equality, development and peace cannot be achieved (Fourth World Conference on Women (FWCW) Platform For Action, 1995:1). Women's role in decision-making is one of the most important questions for consideration in the movement for their empowerment. Keeping in mind the importance of women's participation in decision-making, like the other governments in the world, the government of Bangladesh has initiated efforts to widen the scope of women for participation in the development process.

The representation of women in different categories of occupations and industries is as under:

Table 1: Women representation by occupation (in percentage):

\begin{tabular}{|c|c|c|c|}
\hline Major occupations & $\begin{array}{c}1999- \\
2000\end{array}$ & $\begin{array}{c}2002- \\
2003\end{array}$ & $\begin{array}{c}2005- \\
2006\end{array}$ \\
\hline Professional, technical & 4.7 & 4.1 & 4.4 \\
\hline Administrative, managerial & 0.2 & 0.0 & 0.2 \\
\hline Clerical workers & 1.7 & 1.9 & 1.3 \\
\hline Sales workers & 5.6 & 2.9 & 7.7 \\
\hline Service workers & 15.7 & 9.7 & 2.1 \\
\hline Agriculture, forestry \& fisheries & 47.7 & 58.6 & 68.3 \\
\hline Production \& transport & 24.4 & 22.8 & 16.0 \\
\hline Total & 100 & 100 & 100 \\
\hline
\end{tabular}

Source: Labor Force Survey 1999-2000, 2002-03 and 2005-06, BBS. 
Women's Participation in Managerial Activities: A Study on Employed Women in Selected Enterprises of Bangladesh

Table 2: Growth rate of women's representation in the Occupations:

\begin{tabular}{|l|c|c|}
\hline \multirow{2}{*}{ Major Occupations } & \multicolumn{2}{c|}{ Growth rate (\%) } \\
\cline { 2 - 3 } & $\mathbf{2 0 0 2 - 2 0 0 3}$ & $\mathbf{2 0 0 5 - 2 0 0 6}$ \\
\hline Professional, Technical & $(12.77)$ & 7.32 \\
\hline Administrative, Managerial & $(100)$ & infinity \\
\hline Clerical Workers & 11.76 & $(31.58)$ \\
\hline Sales Workers & $(48.21)$ & 165.52 \\
\hline Service workers & $(38.22)$ & $(78.35)$ \\
\hline Agriculture, forestry \& fisheries & 22.85 & 16.55 \\
\hline Production \& transport & $(6.56)$ & $(29.82)$ \\
\hline
\end{tabular}

Table 3: Industrial representation of women in the labor force (in percentage):

\begin{tabular}{|l|c|c|c|}
\hline Major Sectors & $\begin{array}{c}\mathbf{1 9 9 9}- \\
\mathbf{2 0 0 0}\end{array}$ & $\begin{array}{c}\mathbf{2 0 0 2}- \\
\mathbf{2 0 0 3}\end{array}$ & $\begin{array}{c}\mathbf{2 0 0 5}- \\
\mathbf{2 0 0 6}\end{array}$ \\
\hline Agriculture, forestry \& fisheries & 46.2 & 58.7 & 68.1 \\
\hline Mining \& quarrying & 1.0 & 0.0 & 0.1 \\
\hline Manufacturing & 17.6 & 17.3 & 11.5 \\
\hline Electricity, gas and water & 0.2 & 0.1 & 0.0 \\
\hline Construction & 1.2 & 1.0 & 0.9 \\
\hline Trade, hotel \& restaurant & 6.3 & 2.5 & 4.0 \\
\hline Transport, storage \& communication & 0.6 & 0.3 & 0.6 \\
\hline Finance \& business Services \& real estate & 0.6 & 0.3 & 1.1 \\
\hline Health, education, public administration \& defense & 4.8 & 5.6 & 5.1 \\
\hline Community \& personal services & 21.4 & 14.4 & 8.6 \\
\hline Total & $\mathbf{1 0 0}$ & $\mathbf{1 0 0}$ & $\mathbf{1 0 0}$ \\
\hline
\end{tabular}

Source: Labor Force Survey 1999-2000, 2002-03 and 2005-06, BBS.

Table 4: Growth rate of women's representation in industries:

\begin{tabular}{|l|c|c|}
\hline \multirow{2}{*}{ Major Sectors } & \multicolumn{2}{c|}{ Growth rate (\%) } \\
\cline { 2 - 3 } & $\mathbf{2 0 0 2 - 2 0 0 3}$ & $\mathbf{2 0 0 5 - 2 0 0 6}$ \\
\hline Agriculture, Forestry \& Fisheries & 27.06 & 16.01 \\
\hline Community \& Personal Services & $(32.71)$ & $(40.28)$ \\
\hline Manufacturing & $(1.70)$ & $(33.53)$ \\
\hline $\begin{array}{l}\text { Health, education, public administration } \\
\text { \& defense }\end{array}$ & 16.67 & $(8.93)$ \\
\hline
\end{tabular}




\begin{tabular}{|l|c|c|}
\hline \multirow{2}{*}{ Major Sectors } & \multicolumn{2}{c|}{ Growth rate (\%) } \\
\cline { 2 - 3 } & $\mathbf{2 0 0 2 - 2 0 0 3}$ & $\mathbf{2 0 0 5 - 2 0 0 6}$ \\
\hline Finance\& business Services \& real estate & $(50)$ & 266.67 \\
\hline Transport, storage \& communication & $(50)$ & 100 \\
\hline Trade, hotel \& restaurant & $(60.32)$ & 60 \\
\hline Construction & $(16.67)$ & $(10)$ \\
\hline Electricity, gas and water & $(50)$ & $(100)$ \\
\hline Mining \& quarrying & $(100)$ & Infinity \\
\hline
\end{tabular}

In the above tables it is found that the first largest employment occupation as well as employment industry of women is agriculture which engaged $68.3 \%$ and $68.1 \%$ of women in the year $2005-2006$ respectively. The second largest employment occupation as well as employment industry is production or manufacturing which engaged $16.0 \%$ and $11.5 \%$ of women respectively. But the growth rate of occupational representation of women in agriculture is increasing at a decreasing rate and industrial representation in manufacturing is decreasing at an increasing rate. This decreasing trend does not mean that women are less competent than men. Actually in most cases it is responsible to their multiple roles at home and at work and male predominance etc. Along with others occupations and industries there is a positive growth rate in administrative and managerial occupations and mining and quarrying industries which cannot be measured mathematically.

\section{Objectives of the Study}

The study has been made with an attempt to meet the following objectives:

\section{Major objective:}

To determine the changing role of women in Bangladesh over the past few decades from their traditional home-maker role to non-traditional working women role in managerial activities.

\section{Specific objectives:}

1. To demonstrate the major identifiable occupations of women managers. 
Women's Participation in Managerial Activities: A Study on Employed Women in Selected Enterprises of Bangladesh

2. To identify the position of women managers in those identifiable occupations.

3. To determine the issues relating to low/high participation of women in labor force.

4. To suggest strategies for coping with change.

\section{Rationale of the Study:}

There was a time when a woman was considered pure liability and male was thought to be an asset. "While women represent sixty percent of the total population, they perform nearly two thirds of all working hours, receive only one third of the world income and own less than one percent of world property" (statement from program of Action UN 1980) (Sherchan,1994). Although the statement was made about the general status of women in the world over a decade ago, it holds truth even today as women seem to be more or less in the same status as mentioned above. Such reality inspires me to do the study in the context of Bangladesh.

\section{Methods of the study:}

In the earlier discussions we referred to books, periodicals and journals related to women in management. Bangladesh Standard Industrial Classification of All Economic Activities (BSIC-2001) classifies the industries into 17 categories (Islam, 2008). Among them women are found to work in managerial activities in the following arenas such as are Education, Health, Public services, Banking, Media, Science and technology, Airlines, Business, Social work, Law and Political management. These industries have been selected based on purposive sampling technique for the study purpose. The study period was January, 2012 to May, 2012. All information related to female representation by occupations and industries were collected from different national level sources. Although the data problems in these areas seem insurmountable, an attempt has been made to use information from these national level sources in conjunction with findings from available micro studies to derive some tentative conclusions on the changing position of women at managerial level in the labor market. 


\section{Theoretical Discussion about Keywords:}

\subsection{Women:}

A woman is an adult female human being, as contrasted to men, an adult male, and a girl, a female child. The term woman (irregular plural: women) is used to indicate biological sex distinctions, cultural gender role distinctions, or both (Wikimedia, 2005:1). Women constitute about half of the total population of the country. Apart from the household activities, they are contributing substantially to the national economy. Bangladesh is one of the first developing countries to establish a Ministry of Women's Affairs in 1978, three years after the First World Conference on Women in Mexico. The government has already prepared a National Policy for Advancement of Women and made some noteworthy progress in implementing the National Action Plan, prepared in response to the Beijing Platform For Action (September,1995). In spite of these achievements, the majority of women in Bangladesh have yet to be empowered to participate actively in the social, cultural, economic and political life of the country. Gender discrimination is widespread in all spheres and at all levels albeit, the Constitution of Bangladesh [Article 27, 28(1), 28(2), 28(3), and 65(3)] guarantees equal rights to all citizens clearly incorporated provisions for equal status of women. The latest National Educational Policy (2000) incorporates a separate section on women's education. One of the aims of this policy is to develop self-confidence, human dignity, knowledge and skill among women through providing education and skill training. Other main objectives of this National Policy regarding women are to increase their urge for equal rights; to inspire women and make them capable of participating in national life at all levels, to ensure participation of women in socio-economic development and alleviation of poverty; to help in the economic progress through self-employment. Regarding women, the key policy objectives of The National Health Policy (NHP) 2000 were to reduce the rate of maternal and child mortality and maternal and child malnutrition, increase effectiveness and accessibility of the family planning programs especially by the poor. The policies and programs of the Government, NGOs, and other institutions do not sufficiently address the need for women's empowerment (ADB, 2001:1). 
Women's Participation in Managerial Activities: A Study on Employed Women in Selected Enterprises of Bangladesh

\subsection{Participation:}

Participation is a development approach, which recognizes the need to involve disadvantaged segments of the population in the design and implementation of policies concerning their wellbeing. The strengthening of women's participation in all spheres of life has become a major issue in the development discourse. Socio-economic development cannot be fully achieved without the active participation of women at the decision making level in society. Various scholars define 'Participation' in various ways.

Norman Uphoff (cited in Khan, 1993:111) identified four main kinds of participation, which are distinct but interrelated. They are as follows:

a. Participation in decision making in identifying problems, formulating alternative planning activities, allocating resources etc;

b. Participation in implementation in carrying out activities, managing and operating programs;

c. Participation in economic, social, political or other benefits individually or collectively; and

d. Participation in evaluation of the activity and its outcomes for feedback purposes.

According to Misra (1984:88), "participation means collective and continuous efforts by the people themselves in setting goals, pooling resources together and taking actions which aim at improving their living conditions". S. Rahman (1991:3) has stated that all forms of actions through which citizens take part in the operation of administration may be termed as 'participation'. Here, 'taking part' refers to any level from macro to micro region or it may be of any type e.g. advisory or in decision-making or in implementation etc. According to Human Development Report, "participation means that people are closely involved in the economic, social, cultural and political process that affects their lives" (1993:1). Participation has both a narrow and wider connotation. In a narrow sense participation means some specific action by which the citizen participates for a limited purpose. And in a wider sense participation refers to the role of members of the general public as distinguished from that of appointed officials, including civil servants, in influencing the activities of 
government or in providing directly for community needs (Rahman, 1991:14-15).

\subsection{Management:}

Management is the art, or science, of achieving goals through people. Since managers also supervise, management can be interpreted to mean literally "looking over" - i.e. making sure people do what they are supposed to do. Managers are, therefore, expected to ensure greater productivity or, using the current jargon, 'continuous improvement'. More broadly, management is the process of designing and maintaining an environment in which individuals, working together in groups, efficiently accomplish selected aims (Koontz and Weihrich 1990, p. 4). In its expanded form, this basic definition means several things. First, as managers, people carry out the managerial functions of planning, organizing, staffing, leading, and controlling. Second, management applies to any kind of organization. Third, management applies to managers at all organizational levels. Fourth, the aim of all managers is the same-to create surplus. Finally, managing is concerned with productivity- this implies effectiveness and efficiency. Thus, management refers to the development of bureaucracy that derives its importance from the need for strategic planning, coordination, directing and controlling of large and complex decisionmaking process.

Essentially, management entails the acquisition of managerial competence, and effectiveness in the following key areas: problem solving, administration, human resource management, and organizational leadership. First and foremost, management is about solving problems that keep emerging all the time in the course of an organization struggling to achieve its goals and objectives. Problem solving should be accompanied by problem identification, analysis and the implementation of remedies to managerial problems. Second, administration involves following laid down procedures (although procedures or rules should not be seen as ends in themselves) for the execution, control, communication, delegation and crisis management. Third, human resource management should be based on strategic integration of human resource, assessment of workers, and exchange of ideas between shareholders and workers. Finally, organizational leadership should be developed along lines of interpersonal relationship, teamwork, self-motivation to perform, emotional strength 
Women's Participation in Managerial Activities: A Study on Employed Women in Selected Enterprises of Bangladesh

and maturity to handle situations, personal integrity, and general management skills.

\subsection{Women's Participation in Management globally:}

Women who constitute half of the world population are not fully harnessed as a human resource in the world. Right through history, women have been assigned a secondary status in all religions and culture. However the World Wars proved to be a turning point in the history of mankind and the participation of women in the workforce has started increasing since then. This trend is observed in both development and developing nations.

Today, American women have entered into traditional male domains such as construction, mining and manufacturing of industrial products. 3.7 million American women run sole proprietorship companies out of the total population of 13 million. More than 2,24,000 American women are in the army, navy, air force and marine. The American banking industry is dominated by women professionals and executives. In the U.S. Multinational corporations, women constitute $25 \%$ of the Board of Directors.

In the former Soviet Russia, women were assigned a significant role in nation building activities and today one in every three engineers is a woman in Russia.

The conservative Japanese society has also experienced the changing trend. Between 1976-1989, women have entered the Japanese labour market at a faster rate than men. There are 1655 women managers in 2027 companies listed in Tokyo, Osaka and Nagoya stock exchanges in 1983.

The acceptance of women managers in America has influenced the European countries. The North American based Oil Companies have placed women executives all over Europe. In Britain, merchant bankers have increasingly hired women for key posts, partly because they have seen their successful performance in rival American banks. The tradition of working women is well established in Finland and women face no discrimination as far as their professional lives are concerned.

In consonance with the worldwide trend, Indian women are marching towards self development. Today educated Indian women have made a 
landmark in non-conventional fields like consultancy, marketing, advertising, garment exporting, interior decoration and road construction. They have come forward in considerable number in certain spheres of higher category jobs like civil service, judiciary, foreign services, medicine and civilian air transport (Jeyarathnam, 1994).

Women managers constitute an extremely small proportion of the labour force of Malaysia, of which females account for around onethird. Women classified as employers and as own - account workers represented well below one percent and one fifth of all working women respectively. They formed only 8.6 percent of all employers and $26.8 \%$ of all own account workers in the economy, as compared to $91.4 \%$ and $73.2 \%$ of the two groups who were men (Labour Force Survey Report), (Sieh,1994).

Women in Nepal are least advanced and not aware of their rights due to their own role perceptions and lack of education. This results in a negative view about their own capability and lack of self confidence and initiative. In fact, women's looking for employment outside the home is a new phenomenon. They are less dynamic and less motivated in their occupational job. One of the main reasons for this is that women in Nepal tend to be more dependent on others, also most of the fathers and husbands do not like to see their wives and daughters working with other men (Meera, 1994)

\subsection{Policies on Women's Development in Bangladesh:}

The Fifth Five Year Plan (1997-2002) of Bangladesh recognized that women represent a half of the country's potential for development. The government reconstituted the National Women's Development Council in January, 1997, to provide overall guidance on women's development issues. The National Women's Advancement Policy (NWAP) 2011 announced by the present government aims at improving the lot of the neglected womenfolk of the country, ensure equality of men and women in all spheres of national life including state, society, family, politics, administrative and economic arena, ensure security and empowerment of women, groom up women as educated and efficient human resource, eliminate discriminations and repression on women and girl-child, establish human rights of women, alleviate their poverty and above all ensure their participation in the development process. The key strategies suggested for ensuring gender equity and empowerments are empowering women through providing 
Women's Participation in Managerial Activities: A Study on Employed Women in Selected Enterprises of Bangladesh

technical and vocational education, support for higher education, protection their property rights, removing religious constraints and misconceptions by laws. (National Sustainable Development Strategies (NSDS) Bangladesh, Nov'2008).Establishing equal opportunities for women in all sections of the society with an objective of integrating them into social and economic sphere is a major strategic element underlying the Sixth Five Year Plan (2011-2015). The Sixth Plan strategy embeds the critical role of women in nation building and thus ensures that their needs, rights, entitlements and contributions are appropriately reflected in the Plan document. The human development and social protection strategies underlying the Plan will place particular emphasis on gender aspects of development. Accordingly, the National Women's Advancement Policy (NWAP) 2011 provides for the elimination of all forms of discrimination against women and ensures their rights and equal partnership in development.

\section{Findings and Analysis:}

\subsection{Women in Education Management:}

In Bangladesh the adult literacy rate for the population of 15 years and above is only $34.6 \%$, among the lowest in the world. The literacy rate is far lower for women $(24.2 \%)$ than for men $(45.5 \%)$. Female illiteracy is higher in rural than that of in urban areas. In urban areas $52.5 \%$ of women are literate compared to $20.2 \%$ in rural areas (ESCAP, 1995). Examination of data regarding the number of teachers and educational institutions by level and gender in Bangladesh shows that there is constant increase in the number of educational institutions at primary, secondary, colleges and university levels during past 6-7 years and as a result the number of teachers has also been rising considerably. Presently Bangladesh Educational Statistics (BANBEIS) 2010 shows that in primary schools $45.56 \%$, in secondary schools $23.09 \%$, in colleges $21.30 \%$ and in public universities $22.57 \%$ teachers are women. Previously the proportion of female teachers related closely to the proportion of female institutions in primary and secondary school than to higher levels. However, recently there has been increase in female teachers as well as female heads and executives, though in very small number in all levels. In that perspective, emphasis is placed on training of teachers (about 161 training institute), whereas there is hardly any emphasis on training those heading these institutions in management and related subjects which were not given to them in any stage of their careers. Hence need 
for training female heads of various educational institutions requires no further elaboration.

\subsection{Women in Health Management:}

Employment in the health sector is one of the major preferred fields of employment for women. Total number of registered graduate doctors is 53,063. Among them existing staff of Directorate General of Health Services is 15,666 , of which 3,282 are female representing only $21 \%$ of the strength (HRD data sheet-2011, Ministry of Health and Family Welfare). In view of the concentration of low participation of women in this sector, it is desirable to design and offer courses in health management through relevant agencies.

\subsection{Women in Public (Civil) Services:}

Public service in Bangladesh gives another indication of the concentration of women in very few fields and at lower rates. Although two women Prime Ministers have headed the Government during the last two decades and the leaders of the opposition in Parliament were also women, this does not reflect the gender composition of participation and decision making at the highest policy level. The highest level executive positions are almost exclusively held by men. According to the Ministry of Establishment, 2009, 736 (14.4\% of total Administrative Cadre) women were in Administrative Cadre. Among them only 02 (3.7\% of total Administrative Cadre) women who worked as Secretaries. The following table shows the number of administrative officers by rank.

Table 5: Administrative Cadre at a glance:

\begin{tabular}{|l|c|c|c|c|}
\hline Rank/Position & Male & Female & Total & $\begin{array}{c}\text { \% of Female } \\
\text { officers }\end{array}$ \\
\hline Secretary & 52 & 2 & 54 & 3.7 \\
\hline Additional Secretary & 162 & 13 & 175 & 7.4 \\
\hline Joint Secretary & 995 & 35 & 1030 & 3.4 \\
\hline Deputy Secretary & 1245 & 169 & 1414 & 12.0 \\
\hline Senior Assistant secretary & 1210 & 268 & 1478 & 18.1 \\
\hline Assistant Sectary & 716 & 249 & 965 & 25.8 \\
\hline Total & $\mathbf{4 3 8 0}$ & $\mathbf{7 3 6}$ & $\mathbf{5 1 1 6}$ & $\mathbf{1 4 . 4}$ \\
\hline
\end{tabular}

Source: Ministry of Establishment, 2009 
Women's Participation in Managerial Activities: A Study on Employed Women in Selected Enterprises of Bangladesh

\subsection{Women in Banking:}

The banking industry in the 21st Century is no longer a men's club. Women have stepped out from behind the teller window and back office operations to take prominent roles at large and small institutions. Today, bank owners must seek the best and brightest individuals to fill positions in an increasingly competitive business and employment market. Bank owners also want their employees to reflect their communities and customer bases. They also find that women make up a good portion of their institutions' small business customers. The result is more opportunities for women to work in all aspects of banking, from credit analysis to making loans to running banks. Since 1988, North Western Financial Review has honored the "Outstanding Women in Banking" through-out the Upper Midwest. From nominations received, five women were selected for their contributions to banking. "Outstanding Women in Banking" now serve as mentors and role models for a new generation of bankers, male and female (Sandin and Erik 2007).

In Bangladesh, the fact is that the employment of women and their access to banking arenas are encouraging. But they have identified that they were being discriminated on gender related issues such as male chauvinism, after office work responsibilities, no recognition, inadequate feedback and insufficient career guidance. These issues may culminate in higher absenteeism, turnover, frustration, grievances, etc. and limit the organization's ability to achieve its full potential. To make the industry attractive to women extra efforts like gender friendly environment in all respects are required.

\subsection{Women in Media:}

Mass communication media are attracting women as journalists, feature writers, reporters and also editors in the Press, publication and Information sector. The role of women in Bangladeshi newspapers has progressed from traditional topics of fashion, cookery, home care to cover subjects as diverse as politics, economy, sports, entertainment, social issues etc. In Dhaka, there are 116 daily, 370 weekly, 129 fortnightly, and 270 monthly newspapers. Among 1500 journalists working in Dhaka- based Bangla and English newspapers, the number of women journalists was 60 that is $4 \%$ of the total strength (Ahmed 1998:7-8). As indicated in another survey (Kabir 1998:18), 85\% of the working women journalists are assistant editors, $10 \%$ were recruited as 
reporters, and the rest worked in the editorial department. Similar results were reported in a survey by the Press Institute of Bangladesh (PIB) in Dhaka which revealed that of the 120 women working on 86 Bangladesh newspapers, 62 works as editors, but only 10 (8\% of the total) work as reporters. In Chittagong there are 3 women sub-editors working at daily newspapers (Chepesiuk, 2004:5). A survey conducted by Mass Line Media Centre (MMC) in November 2000 on "What Is the Reality of the Condition and Position of Women Journalists in Newspapers?" surveyed 9 districts of the coastal regions of the country. They found only 1 woman journalist in the Lakshmipur, Feni, and Noakhali districts, as well as a total of 6 others in the Barisal, Zalkhathi, Potuakhali, Pirozpur, Borguna, and Bhola districts (Ferdous, 2001:11). Almost all the women working in newspapers and news agencies in Dhaka and elsewhere in the country are confined to covering soft issues. The women work mostly as sub-editors at desks or look after the specialized feature sections of the newspapers.

In most newspaper offices, the environment is not women friendly; for example, some offices do not even offer a separate toilet for women. Since women are dwarfed by a dominant male presence, they feel like fish out of water and intimidated by their male colleagues, even if some of them are decent and helpful. If a male apprentice fails to perform a job it may go unnoticed with the hope that he will improve one day, but the same failure for a woman will earn humiliating remarks, making them feel unsuitable for the job. Most managers blame the non-professional attitude of women as an excuse to create a barrier to their leadership advancement, insinuating that journalism is a full-time job with which women simply cannot cope (Panday, 2011).

\subsection{Women in Science and Technology:}

There are women scientists in different universities and Government research institutions but the visibility is very poor. A recent statistics shows that in the Bangladesh Agricultural Research Council (BARC), out of the twelve departments only two departments have women scientists $(5.26 \%)$; in Bangladesh Council of Science and Industrial Research (BCSIR), Bangladesh Rice Research Institute (BRRI) and Atomic Energy Center (AEC), the presence of women scientists seems to be the highest $36.3 \%$, second highest $30.1 \%$ and third highest $22.18 \%$ respectively. Poor visibility is also apparent in university teaching and research areas which ranges from 3.1-7.2\%. The most unfortunate case is that in the decision-making regions of the state, women scientists' 
Women's Participation in Managerial Activities: A Study on Employed Women in Selected Enterprises of Bangladesh

visibility is nil, for example, in the Ministry of Science and Technology, there is no women scientist representative to provide suggestions or recommendations for the development of the country.

Such facts show the low and inferior position of women scientists which in turn indicate that women are treated as the marginalized group of the society. Though woman scientists' visibility is low, nonetheless, it shows that women have capacities and intellects for being a scientist. Therefore, it is a question of opportunity and not a question of merit or weaker brain. The situation in Bangladesh is more intricate with economic hardship which is the dominant condition and partly patriarchal social condition (parents are dependent on son but not on daughter) which are responsible for discouraging woman to be a scientist. It appears that Bangladesh society is less biased by andocentric sciences but more biased by the economic condition of the family.

\subsection{Women in Airlines:}

There are now 13 operational airports and Short Take-off and Landing (STOL) ports in Bangladesh. Of these, the airports at Dhaka, Chittagong and Sylhet serve international routes. Air cargo and STOL services have been handed over to the private sector by the government. Biman offers 16 domestic and 102 international flights. Biman currently operates through 7 local and 26 world-wide branch offices. There are only five (05) female pilots in a total of more than a hundred commercial pilots in Bangladesh. Research conducted in 1996 found that Biman had 5,253 non-flying personnel, 30 percent more than Singapore Airlines, a carrier who operated a fleet almost ten times the size of Biman's. The report described Biman as "poorly managed, overstaffed, undercapitalized, and subject to excessive political interference in its day-to-day management. Biman does not recruit any staff directly (i.e. from external qualified candidates) in officer level. Most of them are promoted from lower positions. As a result, the scope of getting quality staff for Biman becomes lower. Hence in all directorates external efficient candidates are deprived, no competitive environment among the staff prevails, the existing staff remains reluctant as they feel that they will be promoted somehow. The promotions that occur are mostly executed through political lobby, which also deter internal competitions. Moreover, it has been alleged that Biman does not want to equip their staff with modern technologies, thus making their productivity even lower. 


\subsection{Women in Entrepreneurship Business:}

Women entrepreneurs are also emerging in Bangladesh. BWCCI (Bangladesh Women Chamber of Commerce and Industry) has over 350 small and medium-sized enterprises and 500 micro-enterprises owned by women members in 8 districts. BWCCI is advocating a voice for over 10,000 women entrepreneurs across Bangladesh. Mostly they are in boutiques business, beauty parlor, restaurant, handicrafts etc. Some women entrepreneurs are a result from self employment using their education, skills and professional expertise; for example doctors operating their own clinics and teachers their own schools. There is a wide scope for the government to support and encourage women entrepreneurs especially through special credit scheme, special training programs, development of network, technical assistance, market linkages, business awareness and other forms of financial supports focused at areas of their specialization to make the women entrepreneurs competent to involve themselves in economic development.

\subsection{Women in Social Work:}

The government is trying hard to integrate the womenfolk of the country into the mainstream of the development process which is one of the main strategies for overall economic development. Poverty, malnutrition, hunger, illiteracy, etc. largely impact womenfolk than the men, and as such women can act as uniquely suitable agents for elimination of these socio-economic maladies. Attainment of reasonable growth rate, alleviation of poverty through generation of production employment opportunities and increased self-reliance are inextricably linked with increased participation of women in development efforts.

The Department of Women's Affairs with a countrywide network, Jatiya Mohila Sangstha-an organization with branches all over the country and the Departments and Organizations of Ministry of Social Welfare promote women's rights, interests and socio-economic opportunities. Appropriate laws have been framed, especially during the Nineties, to stop repression and discrimination against women.

\subsection{Women in Law:}

According to the sources - Bangladesh Bar Council, there are over 41,000 lawyers in Bangladesh. Of them, around 5,000 (12.20\%) are female practicing in different courts, including the Appellate Division 
Women's Participation in Managerial Activities: A Study on Employed Women in Selected Enterprises of Bangladesh

and the High Court Division of the Supreme Court. More than 400 women lawyers are practicing in the High Court and the Appellate Division. Over 250 women on an average are coming into this profession each year.

\subsection{Women in Political Management:}

Historically, women's voting right was established long ago but women's participation in the political and national movement had been negligible. At present both the Prime Minister and the leader of the opposition in Parliament are women. However, their high positions in politics do not reflect the whole scenario of women's position in politics. Both the Prime Minister and the leader of the opposition come from political families. Though both main political parties are under the leadership of women, this has not as yet resulted in massive participation by women in politics and government. Finally, the opportunity for women to participate in politics has opened up. Seats in local, regional, government administrations and the National Parliament have designated a proportion of seats for women. While these numbers are very low, it still signifies progress and the opportunity for greater equality in the future. . The following table shows the number of seats in the national parliament.

Table 6: Seats in the national parliament:

\begin{tabular}{|c|c|c|c|c|c|c|}
\hline Year & $\begin{array}{c}\text { Reserved } \\
\text { seats } \\
\text { (a) }\end{array}$ & $\begin{array}{c}\text { General } \\
\text { seats (b) }\end{array}$ & $\begin{array}{c}\text { Total } \\
\text { seats for } \\
\text { Women } \\
\text { (c=a+b) }\end{array}$ & $\begin{array}{c}\text { Total } \\
\text { seats } \\
\text { for } \\
\text { Men } \\
\text { (d) }\end{array}$ & $\begin{array}{c}\text { Total seats } \\
\text { in } \\
\text { Parliament } \\
(\mathbf{e}=\mathbf{b + d})\end{array}$ & $\begin{array}{c}\text { Women's } \\
\text { participation } \\
\text { in Parliament } \\
\text { (f) }\end{array}$ \\
\hline 1970 & 15 & 0 & 15 & 285 & 285 & $5.26 \%$ \\
\hline 1980 & 30 & 2 & 32 & 298 & 300 & 10.67 \\
\hline 1990 & 30 & 5 & 35 & 295 & 300 & 11.67 \\
\hline 2000 & 30 & 7 & 37 & 293 & 300 & 12.33 \\
\hline 2008 & 45 & 19 & 64 & 281 & 300 & 21.33 \\
\hline 2011 & 50 & 19 & 69 & 281 & 300 & 23 \\
\hline
\end{tabular}

Source (1): Journal of Public Administration by-PATC, Vol-15, June 2000. Dhaka.

Sources (2): Parliament (14.01.2009, 21.03.2009, 17.01.2012), Election Commission (24.03.2009) 
The increasing political involvement has inspired women to contest for the Rural Union Council and Urban Municipal election (there are 1/3 seats reserved for women) more than before. Apart from the reserved seats women can also contest for any of the general seats. The process of selection of the women representatives was on the basis of nominations and/or indirect election. In the last Union Council election (1997) nearly 48,000 women contested for the member post. Around $12,828(26.73 \%)$ women members were elected directly for reserved seats. A total of 20 and 110 women were elected as chairpersons and members, respectively, for general seats.

\section{Issues Related to Low participation of Women in Labor Force:}

The level of female labor force participation is underestimated in Labor Force Surveys (LFS). Nevertheless, due to a consistent methodology it is considered a relatively more reliable source for assessing trends in participation rates. With respect to changes in the occupational structure, the LFS did not till very recently give a sectoral or occupational breakdown of women's employment. The lower representation of women in the workforce suggests that different conditions surround the employment of females including those at the higher levels. There are various reasons for this state of affairs, which are discussed below.

\subsection{Inadequate Implementation of Constitutional and Legal Provisions:}

The status of women still has a long way to go, but women have made several gains in achieving more legal rights in terms of marriage and land rights. More and more women are utilizing the legal system for protection and also asserting their rights. Technically, the constitution of Bangladesh states that all citizens have equal rights regardless of sex, race, class, or ethnicity. However, women have not yet established complete equality in marriage laws and domestic violence. In Bangladesh, women despite having equal rights both under the constitution and most of the other laws, the actual legal status and entitlement are greatly influenced by culture, customs, and norms both social and religious. 
Women's Participation in Managerial Activities: A Study on Employed Women in Selected Enterprises of Bangladesh

\subsection{Existing Customs and Social Practice Detrimental to Women Development:}

In Bangladesh, as a male dominated society, man is considered to be the natural breadwinner and protector of women. Also due to limitations of a developing economy and scarcity of job opportunities it is considered only "just" to give the job to a man if equally quantified men and women compete for the same position. Generally man has understood to be strong to support a family while a woman spends her income on herself or for purchase of luxury goods. Some segments of society consider "women's work" as too much liberal attitude on the part of parents or husbands to allow the women to work. Another point of view is that it suits only to poor and economically depressed classes of women to work who may be compelled to go out of their homes due to economic pressures such as the death of a male breadwinner of the family. Such women are not looked down upon but they are treated with "sympathy". However, a very high code of ethics is set for such women and they are subjected to severe criticism if they simply develop formal relationships with their male colleagues in their work life. Sometimes a girl who works may not get married for this simple fact and even if they do so before marriage they usually leave it as soon they are married.

\subsection{Lack of Proper Institutional Structures:}

Bangladesh is one of the few countries in the world having a separate ministry for women and children. The Ministry of Women Affairs was established in 1978 to fulfill government commitments toward women development. In 1994, Government of Bangladesh reallocated works and responsibilities of the Ministry, which was renamed "Ministry of Women and Children Affairs". In the absence of adequate institutional structure at national level it is difficult to identify the factors that prevent women from contributing to the development of the women. These are political, social, religious, cultural etc. as discussed above. Once these conditioning agents and social pressures are identified, policies to eliminate them need to be formulated and implemented by the relevant agencies. With the setting up of Women's Division and Ministry, a beginning has been made. However it will take a long time before progress could be made to overcome centuries old taboos on women population. 


\subsection{Lack of Suitable Training Facilities:}

Some obstacles arise from women's specific difficulties in demanding promotion because promotions are linked with transfers; or they have difficulties in working late; or because women shy away from responsibility, having a low opinion of their own abilities and a negative attitude to accepting recognition (Mankidy 1986). On the other hand, according to a study by Kamala Srinivasan (1991) Women felt dissatisfied that they were not sent out for training. So their training needs, however, may be greater in view of their less exposure to working environment, segregation, long deprivation, difference in the disciplines studied at college/university level etc. as there was never any serious planning for them in the various professions.

\subsection{Inadequate Supportive Services:}

The facilities and supportive services needed to create conditions conducive to working women such as suitable day care centers, child attendants, economically cooked food, cheap domestic servants etc. are however not easily available or up to the mark in this country. Preference is therefore still given to look after of the youngsters by the mother-in-law or sister-in-law or any other blood relation, if available. These women are, therefore facing the challenge of shouldering the dual responsibilities both of home and work. The higher the position they hold the more responsibilities they take and the harder it becomes for them to attend to the household matters.

\subsection{Built-in Biases against Working Women:}

At office a woman should be twice as good as man to enter or stay in her position, not to say of moving ahead. Any bad situation or problem emerging in her workplace is generally attributed to her presence instead of finding out the root cause which may be due to a defect of the system and may equally occur in a situation controlled by man of same rank or status. Younger women's employment has seen the largest increase. The women, who do not marry, though in very small number, have more chances of rising to high position and are comparatively in better position.

\subsection{Social and Sexual Harassment:}

Traditionally, women in Bangladesh have a lower socio-economic status and very limited access to income generating activities due to a 
Women's Participation in Managerial Activities: A Study on Employed Women in Selected Enterprises of Bangladesh

number of social, cultural and religious barriers (Ahmed et al., 2011a). Women are not only socially discriminated, but also are subject to threat, exploitation and harassment of all sorts (Sarker and Rahman, 2007). Known or heard incidents of sexual harassment at the work place may become deterring factor in the employment of women.

Several legal measures were adopted to safeguard women's legal rights. In 1983, the Cruelty to Women Ordinance was promulgated. This law made kidnapping, trafficking, rape, attempt to cause death, acid throwing, etc., as offenses with a maximum penalty of lifetime imprisonment or the death sentence. The Anti-Terrorism Ordinance (1992) provided for punishment for all kinds of terrorism including harassing and abducting women and children. The Immoral Trafficking Act (1993) provides for punishment for forcing a girl into prostitution. In 1995, the Women and Child Repression (Special Provision) Act was enacted. It provides capital punishment to offenders. An increasing incidence of rape and violation of women by the police and law enforcement agencies in several well-publicized cases brought to light loopholes in its execution. Hence, the Act has been revised and renamed as the Women and Child Repression Prevention Act of 2000. In spite of these provisions, loopholes in existing laws, lack of proper implementation, and the weak commitment of law enforcement agencies are major obstacles. It may be concluded that laws alone cannot be the only deterrent against violence. They must be backed up by conscious public opinion, prompt action, and efforts to change society's attitude towards women.

\subsection{Physical Problems and Discriminatory Practices in Various Occupations:}

The major physical problems identified by women were lack of transport, late working hours, transfers and tours, leave and maternity rules and accommodations. In all services very few women found themselves in higher posts especially after having spent longer years in service. Some respondents feel that highly qualified women were not given jobs because their male counterparts and bosses feel threatened by them. Yet another serious problem pointed out by the women was inadequacy of information system regarding jobs. 


\section{Suggested Strategies for Coping with change:}

\subsection{Proper Implementation of Constitutional and Legal Provisions:}

It is necessary to launch mass awareness program to enable women to identify and articulate their problems. Moreover procedures for seeking legal redress need to be simplified and made less expensive and less time consuming. In fact what is needed is implementation of available provisions for women in letter and spirit.

\subsection{Change of Existing Customs and Social Practice Detrimental to Women's Interests:}

In Bangladesh apart from the obvious pressure to marry early (legal age 18), task of home making, child bearing and rearing as full time occupation. There are many hidden pressures that are brought to bear upon women and prevent them from undertaking productive activity outside home. No radical change can however take place unless there is sincere commitment at the top most level.

\subsection{Strengthening of Institutional Structures and Redefinitions of Their Roles:}

Protection of women's rights as given in the constitution and the status is an important function of the Ministry of Women and Child Affairs. It is believed that this Ministry can have more lasting effect on women development by working in collaboration with other Ministries or Departments dealing with Human Resource Development. The Ministry may, however, continue to fill the gaps in policies and programming for women's rights and continue to perform its multiple roles of a planner, financer, coordinator, advocator and lobbyist within its modest administrative and financial resources. Endeavors are required to focus on affirmative action for women especially in their access to executive and managerial positions.

\subsection{Career Oriented Educational Opportunities:}

Proper education is required to be provided for women when they begin to think of a career as a permanent style of life. Discrimination against women in admissions to professionals' institutions is required to be gradually reduced within a fixed time table. 
Women's Participation in Managerial Activities: A Study on Employed Women in Selected Enterprises of Bangladesh

\subsection{Improvement of Working Conditions for Women:}

It may be pointed out that present working conditions and laws were made by male executives which do not take care of problems of female workers having domestic and child bearing responsibilities. Given a fair chance women executives may define suitable terms and conditions for various occupations.

\subsection{Provision of Adequate Support Services for Working Women:}

To perform their double responsibilities, working women need essential support services like child care centers, working women's hostels, labor market information etc. All these issues need adequate attention and proper planning.

\subsection{Effective Use of Mass Media to Improve Status of Working Women:}

The mass media needs to be effectively used in a strong and serious campaign to raise the nation's consciousness about the importance of women's role in production and their actual and potential contribution to development.

\subsection{Identification and Provision of Suitable Training Facilities for Women:}

Training facilities should be offered to female employees proportionately for making them suitable for assuming higher managerial positions. It is, therefore, necessary that training arrangements made for those women who have put in years of vigorous service and are determined to stay in their professions and move ahead, should be so designed that they are compatible with their other responsibilities. In addition to offering training courses to women in various fields such as education management, health management and office management etc., it is important to design and offer specific whole or part time courses on Women in Development. Such courses may be developed by the agencies already engaged in developing and organizing training courses for HRD may be offered to female or male managers. These courses may highlight the changing role of women in society and their actual as well as potential contribution to development. On the other hand proportionate share of women in top managerial positions can be increased by removing the barriers of promotion of women officers to those positions. For this 
purpose, general attitude of top executives that "females are fit up to mid-level, not beyond that" - should be changed.

\section{Conclusion:}

Women in management have been an important area of research not only for women but also for human resource management. Women's role at managerial levels in different sectors is no less important than that of men. But they are facing expectations and challenges beyond proportion. The hope is that in future women will have greater opportunities to take managerial decisions and they will make visible contributions in the national development of Bangladesh.

\section{References:}

1. AHMED, F.; SIWAR C. and IDRIS, N.A.H., 2011a, Contribution Microcredit for Improving Family Income of the Rural Women in Panchagarh District of Bangladesh, Australian Journal of Basic and Applied Science, 5(5): 360-366.

2. AlFAZ, A. Mass Media and Women,1998, In Women and Media, KHAN N. I. ed., Bangladesh Centre for Development Journalism and Communication (BCDJC), vol.2, no.2, August 1998, Dhaka, Bangladesh.

3. Asian Development Bank (ADB) [2001], Country Briefing Paper on Women in Bangladesh. Program Department (West), Division 2, ADB.

4. Bangladesh: Country on Human Rights Practices (2000).

5. Bangladesh Reports Bureau of Educational Information and Statistics (BANBEIS), 2010.

6. BEGUM, Z. N. T., Status of Women Scientists in the Development of Science and Technology in Bangladesh, Proceedings of the International Conference on Gender Participation in the Development of Science, Dhaka, Bangladesh Academy of Science, November, 2009, p. 48.

7. Biman Bangladesh Airlines-Wikipedia, the free encyclopedia. http://en.wikipedia.org/wiki/Bangladesh

8. Biman Bangladesh Airlines: A Diagnostic Study. http://www.tibangladesh.org

9. CHEPESIUK, R. “Tough Assignment: Working as a Woman Journalists in Bangladesh," The Daily Star, Vol. xiv, No. 143, 14 June 2004. 
Women's Participation in Managerial Activities: A Study on Employed Women in Selected Enterprises of Bangladesh

10. Cover Story: Celebrating 100 Years of International Women's Day; The Star, A weekly publication of Daily Star, Vol.9, Issues 10, March 5, 2010 .

11. DFID, (2004), Operationalising Pro-poor Growth: Bangladesh. Dhaka: DFID 4rth Edition, McGraw-Hill.

12. ESCAP, 1995. Women of Bangladesh: A country Profile, United Nations, New York. 16.

13. FERDOUS, Z."Conditions and Positions of Women Journalists in Newspapers" - Mass Line Media Centre (MMC), Dhaka, Bangladesh, 2001.

14. Fourth World Conference on Women (FWCW) Platform For Action (1995).

15. Human Development Report (1993), United Nations Development.

16. Ibid., p. 145

17. ISLAM, M. N. (2008), Country paper: Bangladesh, presented in UN Workshop on International Economic and Social Classifications; 24-27 November' 2008; Bangkok, Thailand.

18. JEYARATHNAM, M. (1994), Perceptions and Expectations of Women Officers in Public Sector Banks in Tamilnadu, India; presented at the Women in Management workshop of the Association of Management Development Institution in South Asia (AMDISA), $7^{\text {th }}$ February,1994; Dhaka, Bangladesh.

19. KABIR, F. Mass Media and Women, 1998, In Women and Media, KHAN, N. I. ed., Bangladesh Centre for Development Journalism and Communication (BCDJC), vol.2, no.2, August 1998, Dhaka, Bangladesh.

20. KHAN, N. A. (1993).Towards an Understanding of 'Participation'; The Conceptual Labyrinth Revisited in Administrative Change, Vol.XX, Nos.1-2: July 1992-June, pp.106-120. Website: http://www.tibangladesh.org.

21. KOONTZ, H. and WEIHRICH, H. (1990), Essentials of Management, Fifth.

22. LING,S.L.M(1994), Towards Improving Gender Balance in Management: The case of Malaysia; presented at the Women in Management workshop of the Association of Management Development Institution in South Asia (AMDISA), $7^{\text {th }}$ February,1994; Dhaka, Bangladesh.

23. MAHTAB, N., Women in Bangladesh from inequality to Empowerment, Dhaka, Bangladesh, AHDPH, 2007, p.60.

24. MANKIDY, A. (1986), Women Employees: A New Dimension to Human Resource Management in Banks, Indian Banks' Association, special issue. 
25. MISRA, S.N. (1984), Participation and Development, India: NBO Publishers.

26. Nos.1-2: July 1992-June, pp.106-120.

27. NATIONAL SUSTAINABLE DEVELOPMENT STRATEGY (NSDS) BANGLADESH, Final Report, November 2008, Published by the Department of Environment, Ministry of Environment and Forests, Government of the Peoples Republic of Bangladesh.

28. PANDAY, P.K (2011), Still a Male Preserve, Women in Bangladeshi News Industry, "Reporting: Why Are Women Not Coming?" May, 2011.

29. Performance Report (2009-2010) and HRD Data Sheet 2011 of MOHFW. Www.mohfw.gov.bd

30. RAHMAN, M. S. (1991), People's Participation at the Upazilla Level: Problems and Prospects (A Study of Twelve Upazillas in Bangladesh), Rajshahi Programs. New York: UNDP.

31. SHERCHAN, M. (1994), Changing Role of Women Managers: A Nepalese Perspective; p-52, presented at the Women in Management workshop of the Association of Management Development Institution in South Asia (AMDISA), $7^{\text {th }}$ February,1994; Dhaka, Bangladesh.

32. SUK, K.P. and MOBASSER, M.: "Civil Service Reform in Bangladesh: All Play but Hardly Any Work". www.ministry of establishment.

33. SARKER, A.S and RAHMAN, M.H. 2007. The Emerging Perspective of Governance and Poverty Alleviation: A Case of Bangladesh. Public Organiz Rev., 7: 93-112.

34. SRINIVASAN, K. (1991), p 'Women in Banking and Professional Struggles', in Chetana Kalbagh (ed.) Women and Development, Vol. I, New Delhi, Discovery.

35. Status of women in Bangladesh. http://www.country$\underline{\text { studies.com/bangladesh }}$

36. United Nations Entity for General Equality and the Empowerment of Women. www.unwomen.

37. Women's Employment in Bangladesh: Conundrums Amidst Progress. sitersources.worldbank.org. 